Animal Health Research Institute (AHRI)

Assiut Lab.

\title{
ISOLATION AND IDENTIFICATION OF ENTEROBACTERIACEAE FROM FRESHWATER GRAYFISH (PROCAMBARUS CLARKII)
}

(With 4 Tables and 2 Figures)

By

\section{AYA GALAL SAAD EL-DEEN}

(Received at 20/8/2009)

ف

عزل وتصنيف بكتيريا الأمعاء السالبة الجرام ( الأنتيروبكتيرياس)

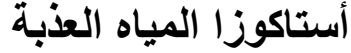

\section{آبيه جلال سعد الدين}

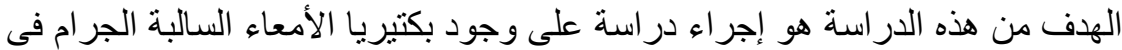

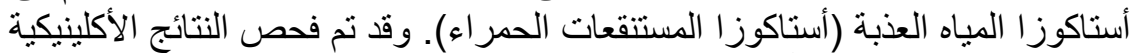

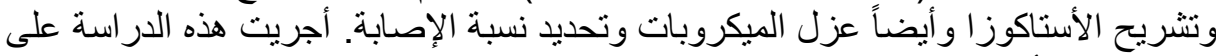

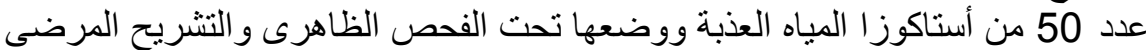

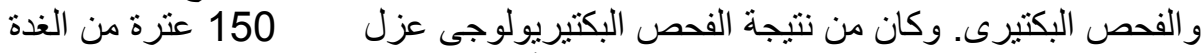

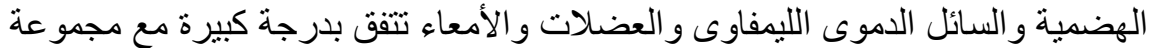

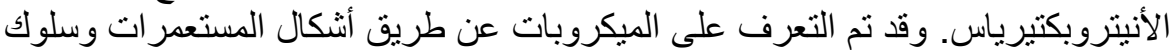

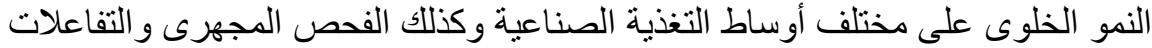

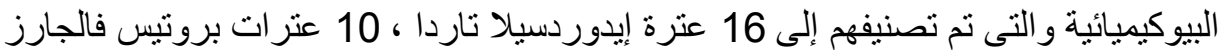

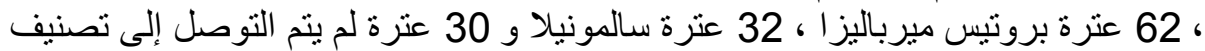

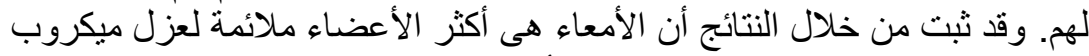

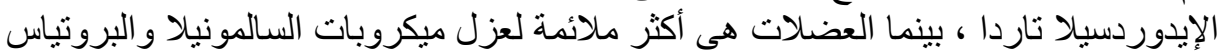

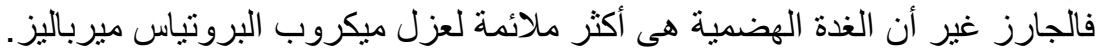

\section{SUMMARY}

The aim of this study was to investigate Enterobacteriaceae infection in freshwater crayfish (red swamp crayfish), Procambarus clarkii, clinical, postmortem findings of examined crayfish, bacteriological examination, rate of infection and organ susceptibility were investigated. 50 freshwater crayfish were subjected to clinical, postmortem and bacteriological examination. Bacteriological examination revealed to isolation of 150 strains from digestive gland, haemolymph, musculature and intestine which are close to morphological and cultural characters to Enterobacteriaceae. Bacteria identification was based on colony 
morphology and culture behavior on various media, microscopic examination, biochemical tests and carbohydrate fermentation. 150 strains were identified as Edweardsiella tarda (16), Proteus vulgaris (10), Proteus mirabilis (62), Salmonella (32) and 30 isolates were not identified. Bacteriological examination revealed the best organ for isolation of E. tarda is intestine, while musculature is the best site for isolation of Proteus vulgaris, and Salmonella. Moreover, hepatopancrease is the best organ for isolation of Proteus mirabillis.

Key words: Enterobacteriaceae, Grayfish.

\section{INTRODUCTION}

The redswamp crayfish, Procambarus clarkia is an autochthanous species from the Northeast of Mexico and South Central US. Hobbs et al. (1989) which was introduced worldwide and has become the dominant freshwater crayfish in almost all area it occupies. Henttonen and Huner (1999).

Introduction of $P$. clarkii to River Nile, Egypt, was through a commercial aquaculture in Giza (Manial-Shetha), in the early 1980 when first immigrants of this species were introduced from USA and the project was shortly terminated due to administrative failure. P. clarkii can be use as a source of animal protein for Egyptian people, many of them suffering from mal-nutrition, where the crayfish muscles contain higher values of protein $(58.6 \mathrm{~g} / 100 \mathrm{~g}$ of female, and $62.6 \mathrm{~g} / 100 \mathrm{~g}$ for male), while the dried carapace can also act as a rich constituent of poultry food Mona et al. (1999). Enterobcteriaceae are a very large family of some 25 genera and more than 100 species of facultatively anaerobic and gram-negative rods. Some species from this family are important pathogens of man, animals and fish Shoots and Bullock (1975). Enterobacteraceae species either Edwardsiella tarda, Proteus vuglaris, Proteus mirabilis and Yersinia were considered of the most important bacterial microorganisms, that causes severe economic losses among fish Farms in many countries as it was reported in most of world countries as, North America, Japans, Taiwan, Thiland and Africa. Bragg (1991), Durborow et al. (1991), Francis et al. (1993) and Baya et al. (1997).

Unfortunately, scarce data present on Enterobacteriaceae in freshwater crayfish in Egypt. This work was planned to fullfil the following objectives, full description of clinical signs and postmortem lesions of naturally infected crayfish. Isolation and identification of 
different strains of Enterobacteriaceae group with giving light on percentage of infection and organ susceptibility.

\section{MATERIALS and METHODS}

\section{Crayfish:}

A total of 50 alive crayfish $P$. clarkii, were collected from the small tributaries of El-Ibrahemia cannal and River Nile, Assiut city. A total length of examined crayfish ranged from 9-16 cm. crayfish were transported to animal health Research Institute in Assiut where clinical and bacteriological examination were conduct.

\section{Clinical and bacteriological examination of crayfish}

Crayfish were examined for any apparent clinical signs or lesions according to Melba et al. (2001). Bacterial sampling were taken from both haemolymph, hepatopancrease, Musculature and intestinal content on salmonella shigella agar (SS agar) (Bio life). Colonies were purified on brain heart infusion (BHI) agar (Bio life).

\section{Bacterial identification}

Bacterial isolates were identified by colony morphology and cultural behavior on brain heart infusion agar (BHI), Trypticase soya agar (TSA) and Salmonella shigella agar (SS agar), microscopic examination (Gram stain and motility test), biochemical tests that include oxidase, catalase, indole, methyl red, voges proskauer, citrate utilization, triple sugar iron reaction (TSI), urease and carbohydrate fermentation (Glucose and sucrose) according to Cruickshank et al. (1975), Hawke et al. (1981), Farmer and Mcwhorter (1984), Brenner (1984) and Whitman (2004)

\section{RESULTS}

\section{Clinical Examination:}

A total of 50 freshwater crayfish showing black spot on the back of the abdomen (Fig. 1), legs, cheliped and tail fin, haemorrhages on hepatopancrease (Fig. 2).

\section{Bacteriological examination:}

Bacterial examination resulted in isolation of 150 strains from hepatpancrease, Musculature, intestine and haemolymph of 50 freshwater crayfish. Primary isolation was done on SS agar. Isolates were identified according to culture and morphological characters as Enterobacteriaceae. 16 strains were suspected to be Edwardsiella tarda. Colonies on SS agar were small, black centers to predominant black colonies. Colonies on BHI and TSA agar were small, round-raised 
transparent colonies. 10 strains were suspected to be Proteus vulgaris and 62 strains were suspected to be Proteus mirabilis. Colonies grew well on SS agar; colonies were whitish or colorless with or without dark center spot. Colonies on BHI, TSA were thin, colorless and transparent. 32 strains were suspected to be Salmonella. Salmonella colonies on SS agar gave flatter and colourless or opaque colonies with small, black center. Salmonella colonies on BHI and TSA give grey-white, moist, smooth colonies.

\section{Bacteriological identification:}

Microscopically, all strains (150) were motile, Gram-negative rods ranged from short coccobacilli to long filaments and oxidase negative. Biochemical characters of isolates are recorded in Table (1).

\section{Frequent distribution of the isolated pathogens}

Isolates were identified according to culture, morphology and biochemical characters as Edwardsiella tarda (16 isolates), Proteus vulgaris (10 isolates), Proteus mirabilis (62 isolates), Salmonella spp. (32 isolates) and 30 isolates were not identified. These results were demonstrated in Table (2).

\section{Percentage of infection among crayfish:}

Percentage of infection among freshwater crayfish examined (50) revealed that 12 crayfish (24\%) were infected with E. tarda, 9 crayfish (18\%) were infected with P. vulgaris. Moreover, number of crayfish infected with P. mirabilis, Salmonella sp. were 36 (72\%), 22 (44\%) respectively. These results are summarized in Table (3). While organ susceptibility of isolated strains were found in Table (4).

Table 1: Biochemical characters of isolated bacteria:

\begin{tabular}{|c|c|c|c|c|}
\hline Test & E. tarda & P. vulgaris & P. mirabilis & Salmonella \\
\hline N. of strain & 16 & 10 & 62 & 32 \\
\hline Gram-stain & \multicolumn{4}{|c|}{ G-ve short rod bacilli } \\
\hline Motility & + & + & + & + \\
\hline Oxidase & - & - & - & - \\
\hline Catalase & + & + & + & + \\
\hline Indole & + & + & - & - \\
\hline Methyl-red & + & + & + & + \\
\hline Vogus-proskauer & - & - & - & - \\
\hline Simmon's citrate & + & + & + & + \\
\hline TSI $\quad \mathrm{H}_{2} \mathrm{~S}$ & + & + & + & + \\
\hline 1S1 Gas & + & + & + & + \\
\hline Urease & - & + & + & - \\
\hline Glucose & + & + & + & + \\
\hline Sucrose & + & - & - & - \\
\hline
\end{tabular}

+ positive

- negative 
Table 2: Frequent distribution of the isolated bacteria ( $n=150$ strains).

\begin{tabular}{|l|c|c|}
\hline \multicolumn{1}{|c|}{ Bacterial species } & No. of strains & Percentage \\
\hline Edwardsiella tarda & 16 & $10.67 \%$ \\
Proteus vulgaris & 10 & $6.67 \%$ \\
Proteus mirabilis & 62 & $40.13 \%$ \\
Salmonella spp. & 32 & $21.33 \%$ \\
Un-identified isolates & 30 & $20 \%$ \\
\hline
\end{tabular}

Table 3: Percentage of infection in freshwater crayfish (50).

\begin{tabular}{|l|c|c|}
\hline \multicolumn{1}{|c|}{ Disease } & $\begin{array}{c}\text { No. of infected } \\
\text { crayfish }\end{array}$ & $\%$ \\
\hline Edwardsiella tarda & 12 & $24 \%$ \\
P. vulgaris infection & 9 & $18 \%$ \\
P. mirabilis infection & 36 & $72 \%$ \\
Salmonella infection & 22 & $44 \%$ \\
\hline
\end{tabular}

Table 4: Organ susceptibility of isolated strains.

\begin{tabular}{|l|c|c|c|c|c|c|c|c|}
\hline \multirow{2}{*}{$\begin{array}{c}\text { Bacteria } \\
\text { spp. }\end{array}$} & \multicolumn{2}{|c|}{ DG } & \multicolumn{2}{c|}{ HL } & \multicolumn{2}{c|}{ M } & \multicolumn{2}{c|}{ I } \\
\cline { 2 - 9 } & No. & $\%$ & No. & $\%$ & No. & $\%$ & No. & $\%$ \\
\hline E. tarda & 2 & $12.5 \%$ & 1 & 6.25 & 2 & 12.5 & 11 & 68.75 \\
P. mirabilis & 24 & 38.7 & 2 & 3.23 & 22 & 35.48 & 14 & 22.58 \\
P. vulgaris & 3 & 30 & 0 & 0 & 4 & 40 & 3 & 30 \\
Salmonella & 10 & 31.25 & 2 & 6.25 & 14 & 43.75 & 6 & 18.75 \\
\hline
\end{tabular}

N.B. DG digestive gland

$\begin{array}{ll}\text { HL } & \text { Haemolymph } \\ \mathrm{M} & \text { musculature } \\ \mathrm{I} & \text { intestine }\end{array}$




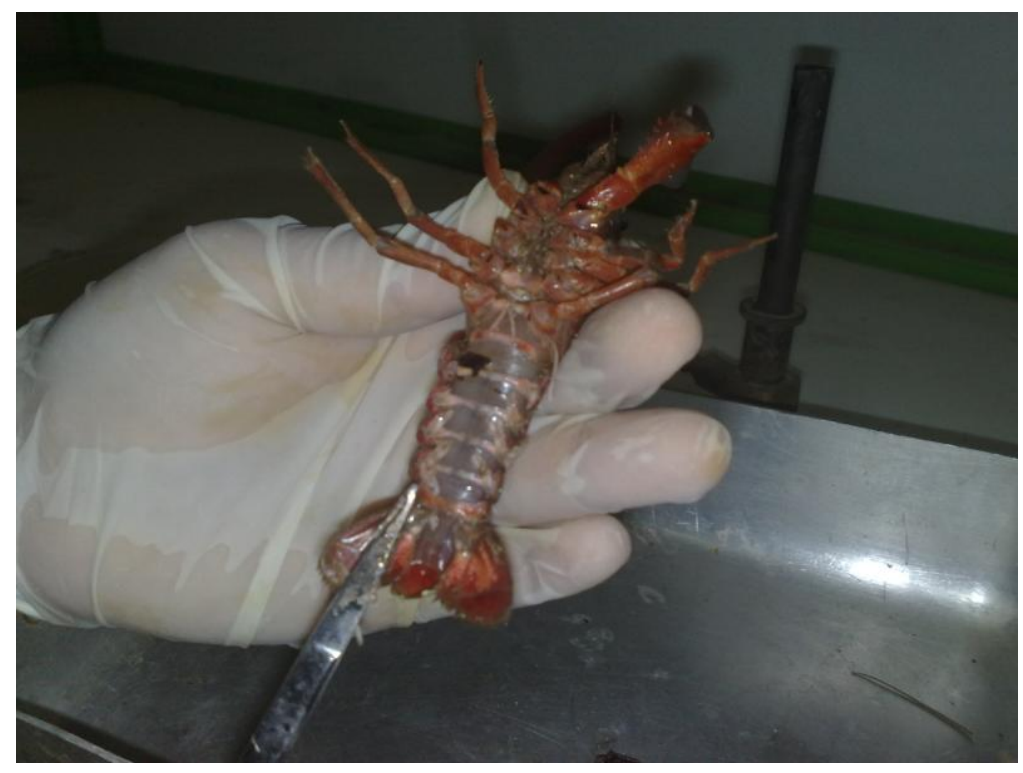

Fig. 1: Freshwater crayfish, Procambarus clarkii naturally infected with Enterobacteriaceae revealing black spot on abdomen.

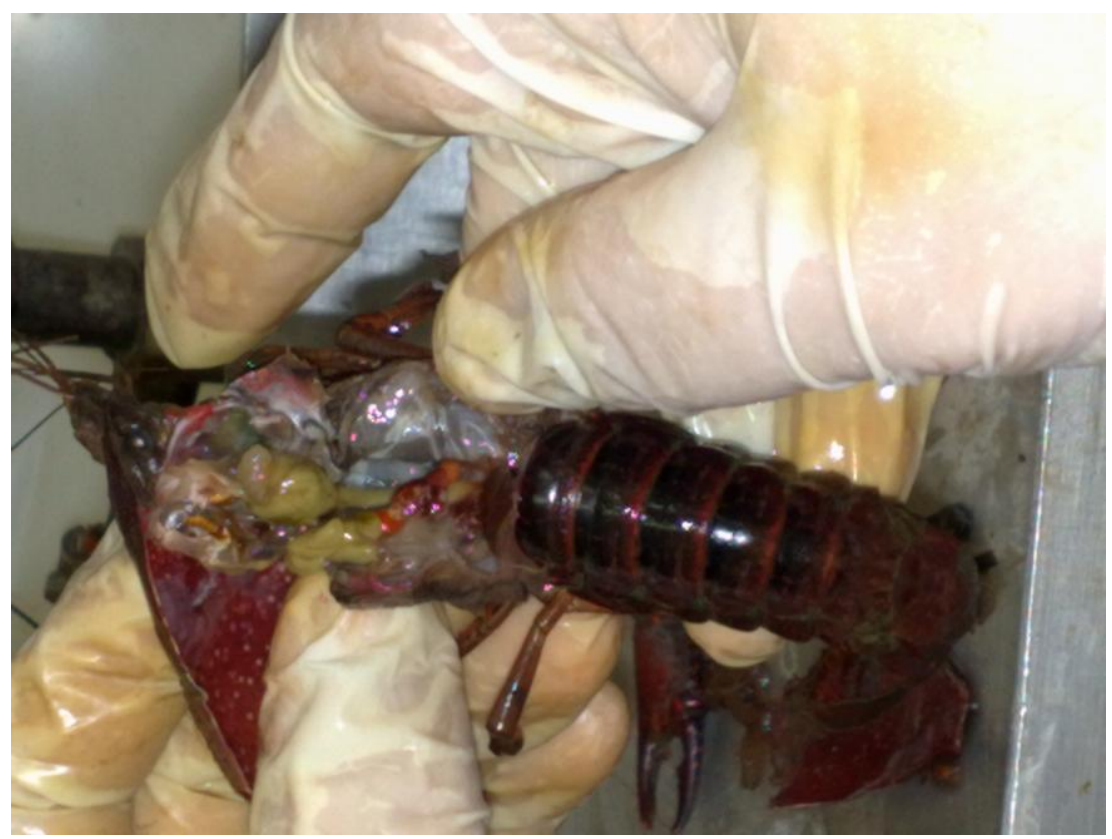

Fig. 2: Freshwater crayfish naturally infected with Enterobacteriaceae showing haemorrage on digestive gland. 


\section{DISCUSSION}

Freshwater crayfish, Procambraus clarkii which recently appeared in River Nile and its resources allover Egypt was bacteriological examination to isolate Enterobacteriaceae. Although Enterobacteriaceae species were successfully isolated from haemolymph, digestive gland, intestine, and musculature of freshwater crayfish examined in this study. No typical clinical signs of infection were evident. This results can be explained by Scott and Thune (1986), Webster (1995), Wong et al. (1995) and Madetoja and Jussila (1996) who reported, asymptomatic bacteremia have been reported in apparently healthy freshwater crayfish including Astacus astacus, Chjerax albidus-destructor, Cherax quadricarinatus and Procambarus clarkii. Prevalence of asymptomatic bacteria was $100 \%$ in investigated apparently healthy Procambarus clarkii.

Black spot were appearing in the examined crayfish. This observation may be attributed to immune system of crayfish Soderhall and Ajaxon (1982). 150 strains of Enterobacteriaceae were isolated from examined freshwater crayfish. El-Sherry (2009) isolated 64 strains of Enterobacteriaceae from 48 freshwater crayfish. These results can be exaplined by Tubiashi et al. (1975) and Davis and Sizemore (1982) who reported the bacteria inhabited the ecosystem in which the crayfish live and were found in water and sediments, resident on the exoskeleton or in the gut. They enter the hemocoel through minor wounds, gastrointestinal tract and other different routs. Fish grown in ponds containing waste water accumulate Enterobacteriaceae, that penetrate into muscle tissue of fish Tomas et al. (1983). Otherwise, Baya et al. (1997) have reported fish living in river water that receives city sewage carry a significantly higher number of bacterial species in comparison with fish from less polluted water. 150 isolates of Enterobacteriaceae were identified according to culture, morphology and biochemical characters as E. tarda (16), Proteus vulgaris (10 strains), Proteus mirabilis (62 strains), Salmonella (32 strains) and (30 strains) non-identified strains. Results of biochemical tests were nearly similar to those reported by other investigation including, Farmer and Mcwhorter (1980), Grimont et al. 1980), Farmer (1995), Whitman (2004) and Ahmed and El-Kamel (2006). Edwardsiella tarda was isolated from freshwater crayfish. Wyatt et al. (1979) can isolate E. tarda from $100 \%$ examine crayfish. Result showed that E. tarda was isolated from intestine higher than from digestive gland, Haemolymph and musculature. This could be due to infection with $E$. tarda begin from intestine and spread to other visceral 
organs. Proteus vulgaris (10) were isolated from crayfish. Toumanoff (1968) was isolated P. vulgaris from Procambarus clarkii and Orconectes timosus. P. vulgaris was isolated from musculature at higher rate than hepatopencrease, Haemolymph and intestine. These result nearly to Thomas et al. (1983) which have reported that fish grown in pond containing waste water accumulate Enterobacteriaceae, that penetrate into the muscle of fish. 32 strains salmonella was isolated and these result can be attributed to, fresh water crayfish are typical found in warm freshwater rivers, slowflowing water, reservoirs and irrigation system which are subject to sewage, waste water, mud and dead animals. Salmonellae are typical mesophilic bacteria. However, their main as water reservoirs, contaminated with human and animals excerete may harbour salmonella. In particular shellfish growing in contaminated water may accumulate salmonella and raw oysters (Ahmed, 1991). Salmonella has also been detected in several crustacean and molluscan product from Indian and Malaysia (D'Aoust, 2000). While Elmossalami and Emara (1999) reported that Salmonella could not be isolated from any of the examined $P$. clarkii.

\section{REFERENCES}

Ahmed, F.E. (ed.) (1991): Seafood safety, National Academy Press. Washington DC, USA.

Ahmed, SH.M. and El-Kamel, A.A. (2006): Proteus vulgaris, an Emerging fish pathogen in Egypt. Assiut Veterinary Medicine Journal. Vol. 52, No. III: 36-50.

Baya, A.M.; Romande, D.L.; Green, D.E.; Navarro, R.B.; Evans, J.; May, E.B. and Torono, A.E. (1997): Edwardsiellosis in wild stripped bass from the chesapeak Bay. J. Wild Disease. 33 (3): 517-525.

Bragg, R.R. (1991): Health status of Salmonids in River system in Natal. Isolation and Identification of bacteria. J. Vet. Res. 58 (2): 67-70.

Brenner, D.J. (1984): Family Enterobacteriaceae in: Kairg, N.R. and Holt, J.G. eds. Bergey's manual of systematic bacteriology, Vol. I: Williams and Baltimore, USA, pp. 409-516.

Cruickshank, K.R.; Duguid, J.P.; Marmion, B.P. and Swain, R.H. (1975): Tests for identification of bacteria in: Medical microbiology $12^{\text {th }}$ Ed. Vol. II. Churchill Livingstone, Edinburgl, London and New York, pp. 170-189. 
D'Aoust, J.Y. (2000): Salmonella in: Lund, B.M., Baird-Parker, T.C. and Gould, G.W. (eds.). The microbiological safety and quality of foods. Aspen, Gaithersberg, Maryland, USA. Pp. 1233-1299.

Davis, J.W. and Sizemore, R.K. (1982): Incidence of Vibrio spp. associated with blue crabs Callinectes sapidus, collected from Galveston Bay Texas USA. App. Environ. Micro. 43 (5): 1092-1097.

Duborow, R.M.; Taylor, P.W.; Crosby, M.D. and Santucci, T.D. (1991): Fish mortality in the Missippi catfish farming industry in 1988: Causes and treatments. J. Wild Disease, 27 (1): 144-147.

Elmossalami, M.K. and Emara, M.T. (1999): Safety and quality of freshwater crayfish, Procambarus clarkii, in the Rive Nile. Digital object identifier 43 (2): 126-8.

El-Sherry, Y.M. (2009): Role of crayfish in transmission of fish diseases. M.V. SC Thesis. Faculty of Veterinary Medicine, Assiut University.

Farmer, J.J. (1995): Enterobacteriaceae: Introduction and identification 1995. In Murray, PR., Baron, EJ., Pfaller, MA, Tenover, CF., Yolken, RH. (eds). Manual of Clinical Microbiology. $6^{\text {th }}$ ed. ASM Press, Washington D.C. p. 438-464.

Farmer, J.J.III and Mcwhorter, A.C. (1980): Genus X, Edwardsiella. Ewing and Mcwhorter (1965). In: Kairg, N.R. and Holt, J.G. (eds) Bergey's manual of systematic bacteriology, Vol. I, Williams and Baltimore, USA, pp. 486-491.

Francis-Floyd, R.; Reed, P.; Bolon, B.; Estes, J. and Mckinney, S. (1993): An epizootic of Edwardsiella tarda in large mouth bass (Micropterus slamoides). J. Wild Disease. 29 (2): 334-6.

Grimont, P.A.D.; Grimont, F.; Richard, C. and Sakazaki, R. (1980): Edwardsiella hoshinae, a new species of Enterobacteriaceae. Current Microbiology, 4: 347-351.

Hawke, J.P.; Mcwhorter, A.C.; Steigerwalt, A.G. and Brenner, D.J. (1981): Edwardsiella ictaluri sp., the causative agent of enteric septicemia of catfish. Int. J. of systemic bacterial. 31: 396-400.

Henttonen, P. and Huner, J.V. (1999): The introduction of alien species in Europe: a historical introduction. In: Gherardi, F. and Holdich, D.M. Editors. 1999. Crayfish in Europe as Alien species. Crustacean issues II, A.A. Balkema, Rotterdam. Pp. 13-22. 
Hobbs, H.H.; Jass, J.P. and Huner, J.V. (1989): A review of global crayfish introductions with particular emphasis on two North America species (Decapoda, Cambaridae). Crustaceana. 36: 299-316.

Madetoja, M. and Jussila, J. (1996): Gram-negative bacteria in the haemolymph of noble crayfish, Astacus astacus, in an intensive crayfish culture system. Nordic Journal Freshwater Research, 72: 88-90.

Melba, G.B.; M cGladdery, S.E.; East, I. and Subasinghe, R.P. (2001): Asia Diagnostic Guide to Aquatic Animal Diseases. FAO. Fisheries technical. Paper 402/ 2.

Mona, M.H.; Geasa, N.M.Sh.; Sharshar, KH.M. and Morsy, E.M. (1999): Chemical composition of freshwater crayfish (Procambarus clarkii) and its nutritive value. Egypt. J. Aquat. Biol. Fish. 4 (1): 19-34.

Scott, J.R. and Thune, R.L. (1986): Bacterial flora of hemolymph from redswamp crawfish, Procambarus clarkii (Girard), from commercial ponds. Aquaculture. 58: 161-165.

Shotts, E.B. and Bullock, G.L. (1975): Bacterial diseases of fishes: diagnostic procedures for Gram-negative pathogens. Journal Fisheries Research Board of Canada. 32: 1243-1247.

Soderhall, K. and Ajaxon, R. (1982): Effect of quinines and melanin on mycelial growth of Aqphanomyces spp. and extracellular protease of Aphanomyces astaci, a parasite on crayfish. J. Invertebr. Pathol. 39: 105-109.

Thomas, W.H.; Charles, P.G.; Scott, I.I. and Mike, F. (1983): Bacteriological, virological and chemical evazlution of a waste water-aquaculture system. Water Res. Vol. 17, No. 12, pp. 1749-1755.

Toumanoff, C. (1968): Infections Bacteriennes chesles ecrevisses: troisieme note (ii) Pseudomonaceae Pseudomonas alcaligenes Monias 1928 et Alcaligenes (Bacillus faecalis alcaligenes Petruschkly 1986) et quelques bacteries proches: In-Certae sedis. Bulletin Francais de Pisciculture. 228, 102-111.

Tubiashi, H.S.; Sizemore, R.K. and Colwell, R.R. (1975): Bacterial flora of the haemolymph of the blue crab, Calinectes sapidus: most probable numbers. Applied Microbiology, 29: 388-393.

Webster, M.S. (1995): The isolation and identification of bacterial flora from the Redclaw Crayfish, Cherax quadrincarinatus. Honours Thesis James Cook University of North Queensland, Townsville, Australia. 111 p. 
Whitman, K.A. (2004): Finfish and Shellfish, Bacteriology Manuall Techniques and procedures. $1^{\mathrm{st}}$. Iow state press.

Wong, F.Y.K.; Fowler, K. and Desmarchelier, P.M. (1995): Vibriosis due to Vibrio mimicus in Australian freshwater crayfish. Journal of Aquatic Animal Health. 7: 284-291.

Wyatt, L.E.; Nickelson, R.H. and Vanderzant, C. (1979): Edwardsiella tarda in freshwater catfish and their environment. Applied and Environment Microbiology. 38: 710-714. 